\title{
Implements of wild boar canines during the Neolithic and Chalcolithic at the Lower Danube
}

\author{
Monica Mărgărit ${ }^{1}$, Adina Boroneanț ${ }^{2}$ \\ 1 Valahia University of Târgovişte, Târgovişte and "Vasile Pârvan" Institute of Archaeology, Romanian Academy, \\ București, RO; monicamargarit@yahoo.com \\ 2 "Vasile Pârvan" Institute of Archaeology, Romanian Academy, București, RO; borozo@gmail.com
}

\begin{abstract}
This paper discusses the technological exploitation and transformation of wild boar teeth into tools during the Neolithic and the Chalcolithic north of the Lower Damube. Four main variables were taken into consideration: raw material procurement, blank production, object manufacture, and equipment maintenance. Tool finds from various prehistoric sites in Romania were compared, aiming to identify their impact on the economy of the prehistoric communities, and to determine possible variations in their number/ways of use during early prehistory. Tool typology is poor. The finds studied showed different degrees of use-wear, as well as systematic re-sharpening of the active front. In addition, finished tools are predominant in comparison to the sub-products of the chaîne opératoire. The almost total lack of blanks may suggest no stocking was taking place. The entire tooth was used, resulting at times in several implements. Our experimental program, by following closely the technical transformation schemes indicated by the archaeological specimens, suggests that such tusk tools were used for woodworking.
\end{abstract}

KEY WORDS - Neolithic; Chalcolithic; Lower Danube; Romania; wild boar; canines; tools; technological and use-wear analysis; experimental replicas

\section{Orodja iz podočnikov divjih prašičev v neolitiku in halkolitiku v Spodnjem Podonavju}

\begin{abstract}
IZVLEČEK - V prispevku obravnavamo uporabo in tehnologijo preoblikovanja zob divjih prašičev v orodja $v$ neolitiku in halkolitiku na območju severno od Spodnjega Podonavja. Upoštevali smo štiri ključne spremenljivke: zagotavljanje surovin, proizvodnjo polizdelkov, izdelavo predmetov in vzdrževanje opreme. S primerjavo orodij iz različnih romunskih prazgodovinskih najdišč smo ugotavljali njihov vpliv na gospodarstva prazgodovinskih skupnosti in variabilnosti v številu/načinu uporabe $v$ starejši prazgodovini. Tipologija orodij je slaba. Analiza je pokazala različne stopnje obrabe in ponovno ostrenje. V produkcijski verigi je v primerjavi s polizdelki več končnih izdelkov. Majhno število prvih kaže na to, da njihove zaloge ni bilo. Zob je bil uporabljen v celoti, včasih za izdelavo več orodij. S pomočjo našega eksperimentalnega programa smo lahko sledili tehničnim transformacijam orodij, ki kažejo, da so bila uporabljena za obdelavo lesa.
\end{abstract}

KLJUČNE BESEDE - neolitik; halkolitik; Spodnje Podonavje; Romunija; merjasec; podočniki; orodje; analize tehnologije in sledi uporabe orodij; eksperimentalne replike

\section{Introduction}

Tools of wild boar canines were frequently used by Mesolithic communities throughout Europe (e.g., Marquebielle 2014), but during the Neolithic (e.g., Sidéra 2012) their presence is rarer, although they were never totally absent. The same phenomenon was noted north of the Lower Danube, in southern and eastern Romania. The earliest wild boar canine tools were documented at the Mesolithic sites in the 
Iron Gates on both banks of the Danube (e.g., Vlasac (Srejović, Letica 1978), Icoana (Mărgărit et al. 2017a), Ostrovul Banului (Mărgărit et al. 2017b)), as an important component of the toolkit of the local foragers. At Icoana (Mărgărit et al. 2017a), the number of wild boar canine tools is comparable to that of bone and antler implements; the total osseous assemblage ( $\mathrm{n}=484$ items) reflects a well-balanced use of the available osseous raw materials (bone $36 \%$, antler 35\%, and tooth 29\%). Debitage waste was present at the site (Mărgărit et al. 2017a) and blanks were recovered from the Ostrovul Banului downstream site (Mărgărit et al. 2017b), suggesting that tusk processing took place in situ. While Mesolithic tusk artefacts in our area of interest have received extensive publication (Mărgărit, Boroneant 2017a; 2017b; Mărgărit et al. 2017a; 2017b), the situation is somewhat different for the Neolithic and Chalcolithic assemblages.

Taking this into consideration, the aim of this paper is to further explore the transformations of the wild boar canine tools 1 during these two periods in southern and eastern Romania. Our objective was to characterize wild boar canine exploitation patterns during the Neolithic and the Chalcolithic through the analysis of four main variables: raw material; blank production (debitage method); manufacture of implements and maintenance of the toolkit, as well as initiate a discussion on the economic and technological implications of wild boar tusk exploitation, starting from our own experimental reconstructions. Several sites attributed to different cultural groups were selected, based mainly on the availability of tusk artefacts and size of the assemblage. The paper focuses on our own study of the material, but also takes into account previous work (Tab. 1, see below).

\section{Archaeological and cultural framework}

\section{The Neolithic}

Radiocarbon dates for the Early Neolithic - the Starčevo-Criș-Körös cultural complex - cluster between c. 6000-5400/5300 cal BC, although a handful of dates fall outside both ends of the interval. The only assemblage directly studied here originates from Măgura Buduiasca (Teleorman County), south-western Romania. Previous technological studies referred to a few sites in Oltenia at Cârcea-La Hanuri and CârceaViaduct, and eastern Romania at Trestiana and Grumăzești (Marinescu-Bîlcu, Beldiman 1997; Beldiman 2007; Beldiman, Sztancs 2013). Tusk imple- ments were mentioned at least at two Early Neolithic sites on the right bank of the Danube in the Iron Gates (Alibeg, Cuina Turcului). In most cases, such artefacts originated from pithouses (whether the floor or the infill is not always clear) and only rarely from the cultural layer.

The Dudești culture (c. 5500-4800 cal BC) and later on the Boian followed the Starčevo-Cris in southern Romania, while in the Iron Gates the latter culture was succeeded by the Vinča $(c .5700-4800$ cal BC). The only Dudești assemblage studied came from pitfeatures at Măgura Buduiasca (Teleorman County, c. 5300-5000 cal BC; Mirea 2011). Some interesting tusk implements (grave goods) came from the Late Dudești/Early Boian necropolis from Cernica (Ilfov County, c. 5200-5000 cal BC; Stratton et al. 2019). One artefact came from a Vinča B2 context at Liubcova-Ornita where the occupation was dated based on one charcoal sample to $c .5230-5000 \mathrm{cal} \mathrm{BC}(\mathrm{Lu}$ ca, El Susi 1989).

The Precucuteni culture followed the Starčevo in eastern Romania. Two sites from Iași County offered data pertinent to the present study: Isaiia - Balta Popii and Târgu Frumos - Baza Pătule. The technology of the tusk implements from the latter site were detailed and both presented by Andreea Vornicu $(2014 a)$. The former site was assigned based on pottery typology to the Precucuteni culture, phases II and III; occupation of the site falls within the interval between 4620-4440 cal BC (Ursulescu et al. 2020). The only date from the latter site (seen as Precucuteni III) indicates occupation during the 48004550 cal BC interval (Ursulescu et al. 2005). The artefacts originated from features identified as houseplatforms.

\section{The Chalcolithic}

Four assemblages originating from sites of the $\mathrm{Gu}$ melnita culture (c. 4600-3850 cal BC; Bem 2001) were studied: Bordușani-Popină (Ialomița County), Căscioarele (Călărași County), Hârșova 'Constanța County) and Vitănești (Teleorman County). Earlier publications report wild boar tusk tools from house features at Grădistea-Fundeanca (Dumitrescu 1933a) and Gumelnita (Dumitrescu 1924; 1925), while more recently their presence in funerary contexts was reported at Pietrele (Hansen et al. 2011).

For the Cucuteni culture (c. 4650-3450 cal BC; Bem 2001), the assemblage the present author studied di-

1 The paper does not discuss adornments manufactured from this particular raw material unless they were derived from former tools. 
rectly, came from Drăguseni (Neamt County). Pottery typology indicated the site as Cucuteni A4 (Marinescu Bîlcu, Bolomey 2000). Previous technological studies focused on the small assemblages from Costesti - Cier (Vornicu 2014b) dated to the Cucuteni A2-3, with no radiocarbon dates available (Boghian et al. 2014) and Berești - Dealul Bulgarului, Galați County (Beldiman et al. 2012) a Cucuteni A3 site.

A small number of implements were reported mainly from old excavations at Bodești - Cetătuia Frumusica, Neamt County - Cucuteni A, A-B and B (Mătasă 1946); Poienești, Vaslui County (Vulpe 1953) Cucuteni A; Ruginoasa, Iași County (Dumitrescu 1933b) - Cucuteni A. The only recent finds came from Fulgeriș - La trei cireși, Bacău County, a Cucuteni A3 site (Iatcu et al. 2016). All Cucuteni finds were associated with house features/platforms.

\section{Methods}

The methodology employed is based on the macroscopic and microscopic analysis of the technological and wear marks present on the archaeological artefacts, supplemented by experimental data. During the first stage of our research, we focused primarily on the preforms, blanks and manufacturing waste, and then on the finished pieces. All artefacts were observed under the microscope for the correct characterization of the technological marks. The second stage aimed to reconstruct the sequence of the manufacturing gestures and the transformation scheme from the raw material to the finished implement. based on the reported archaeological context and associations.

Starting with the data obtained from the archaeological assemblages, replicas were created to assess all the variables involved in the techniques of processing the tusk implements (technological gestures, time required for each operation, tools employed, re-sharpening actions, etc.). This allowed for the correct evaluation of the material costs and the energy invested in the manufacture of these types of artefacts, from the acquisition of the wild boar canines, to the use and the discard of the finished tools. Subsequent to their production, the experimental implements were used in the manner suggested by the relevant archaeological publications. Finally, various parameters of the two categories of implements (archaeological and experimental) were compared (e.g., the morphology of the active end following use, the use-wear marks, their resilience over time, etc.) in order to assess the validity of the previously suggested functions of the archaeological artefacts.

\section{Raw material}

Wild boars are adaptable mammals, mostly omnivorous (Albarella et al. 2006). A characteristic of the wild boar dentition is the presence of large, rootless and continuously growing permanent canines (tusks) in males (Schmid 1972) which serve for defence, finding food and as powerful weapons used against other males during the mating season. When the up-
Microscopic examination and photography were undertaken using a Keyence VHX-600 digital microscope at magnifications between $\times 30$ and $\times 150$. Our methodologies for recording morphological and morphometric attributes, and for the analysis of the technological and use-wear marks, were developed with reference to previous studies on tooth tools from prehistoric contexts (e.g., Chiquet et al. 1997; Maigrot 2001; 2005; Marquebielle 2009; 2014; Sidéra 2012). None of the artefacts available for study has been directly dated. Therefore, period assignments are

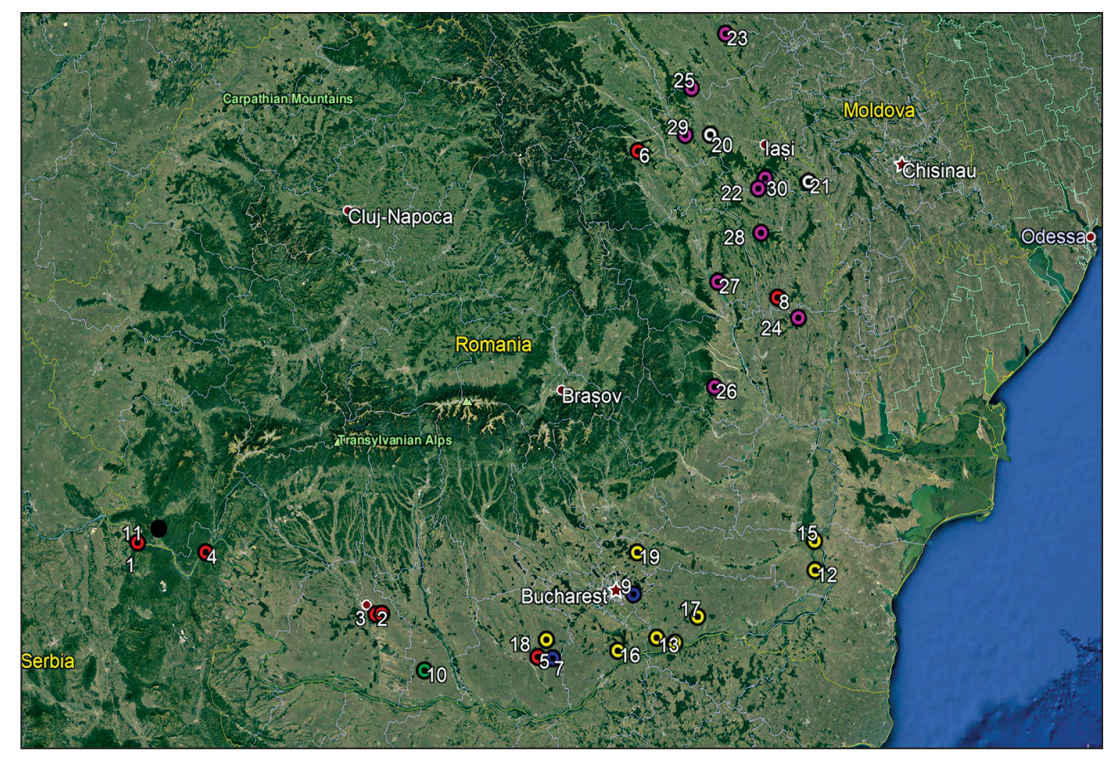

Fig. 1. Map of the sites mentioned in the text: red Starčevo Criş; blue Dudești; green Vinča; black Vădastra; yellow Gumelniţa; white Precucuteni; magenta Cucuteni. 
per canine is absent, the lower canine can reach an enormous length (Konjević et al. 2004).

They are triangular in section, curved and directed towards the exterior. The proximal end is hollow. Only the anterior internal and external faces are covered with a thin layer of enamel. The lower canines - used for toolmaking - have a natural wear facet towards the distal extremity, resulting from the abrasion against the upper canines (Marquebielle 2014).

At the sites in discussion, only wild boar teeth (Sus scrofa Linnaeus, 1758; Gentry et al. 2004) seem to have been used to make various tools, those of domestic pig (Sus domesticus, Erxleben, 1777; Gentry et al. 2004) do not bear any marks of technological modifications. The situation has both economic and technological explanations. According to certain archaeozoological studies (Bălășescu et al. 2005a), at the Neolithic and Chalcolithic sites in the Lower Danube region male domestic pigs generally did not live beyond 1.5 years. It is extremely unlikely that

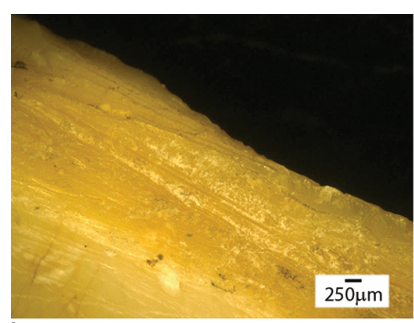

b

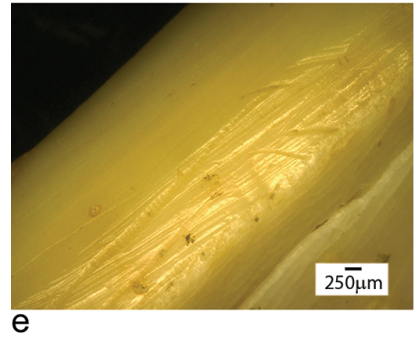

e

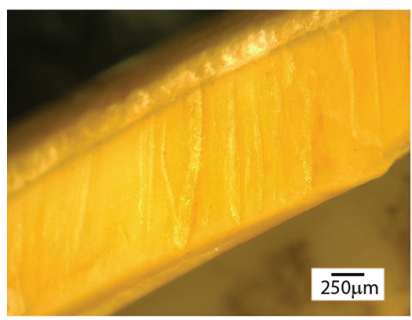

$\mathrm{h}$

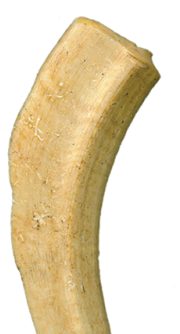

a
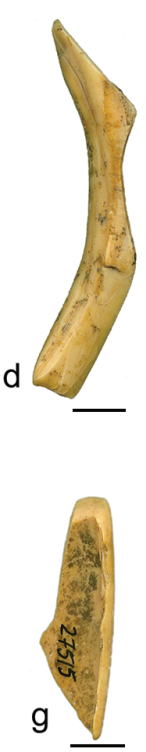

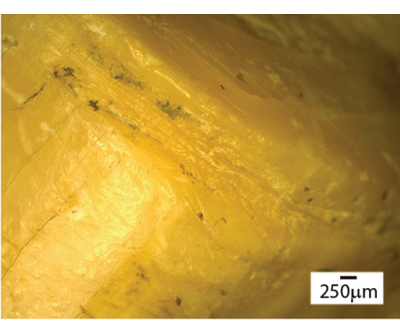

C

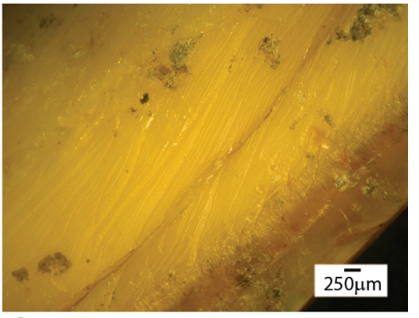

f

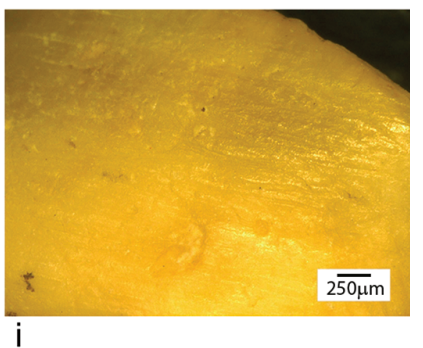

Fig. 2. Teeth artefacts from Măgura-Buduiasca (Starčevo-Criș culture): a blank; b-c sawing marks; d scraper; e grooving marks; f, i scraping marks; g bevelled tool; h abrasion marks. prior to that age they developed canines of the size we identified at the tusk artefacts we present. Female domestic pigs reach maturity, and cases of rather old sows have been documented, but their canines are too small for such purposes.

\section{The archaeological assemblages}

\section{The Starčevo-Criş culture}

Significant information was provided by the site at Măgura-Buduiasca, Teleorman County (Beldiman, Sztancs 2009; 2013). The only blank (Fig. 2.a) still preserving part of the proximal end of the tooth indicates the tooth was extracted from the bone complete. The tip of the tusk was sawn off with a flint tool (Fig. 2.b-c). Subsequently, the blank was bipartitioned longitudinally by percussion.

Finished tools included scrapers (six) and bevelled tools (1). The scrapers (Fig. 2.d; see also Beldiman, Sztancs 2009.Fig. 14) were also made on blanks obtained by splitting the canine longitudinally. The cutting edges were adjusted by abrasion over variable areas. At two specimens, the interior surface was regularized by longitudinal scraping. The active front with a concave facet was created exclusively by scraping. The concavity developed longitudinally, is of variable depth on different artefacts, and ends in a false point.

A single specimen was obtained by bipartition, combining grooving and indirect percussion (Fig. 2.e). The technological marks left by this operation are still visible. Subsequently, the entire interior surface of the piece was shaped by longitudinal scraping (Fig. 2.f). The active front displays a convexo-concave area and a point, which created two scraping edges.

The only bevelled tool (Fig. 2.g) was made from the proximal extremity of the tooth. It is fractured both longitudinally and transversely. The tooth was bipartitioned by percussion, with the abrasion of the cutting edges (Fig. 2.h). The active front creat- 
ed by the transversal scraping of the distal extremity is present only on the interior surface. The visible technological marks overlap areas of use-wear, indicating re-sharpening (Fig. 2.i).

From Grumăzești (Neamt County) was recovered one tooth broken from the jaw by direct percussion/fracturing using a lithic tool (Marinescu-Bîlcu, Beldiman 1997; Beldiman 2007.156). Two 'polishers' from Trestiana were also reported (Vaslui County; Popussoi, Beldiman 2001; Beldiman 2007.93, type I B7; Beldiman, Sztancs 2013). Their manufacturing stages were similar to what we observed in the Măgura assemblage.

In south-western Romania sporadic finds were mentioned at the Early Neolithic sites at Cârcea-Viaduct
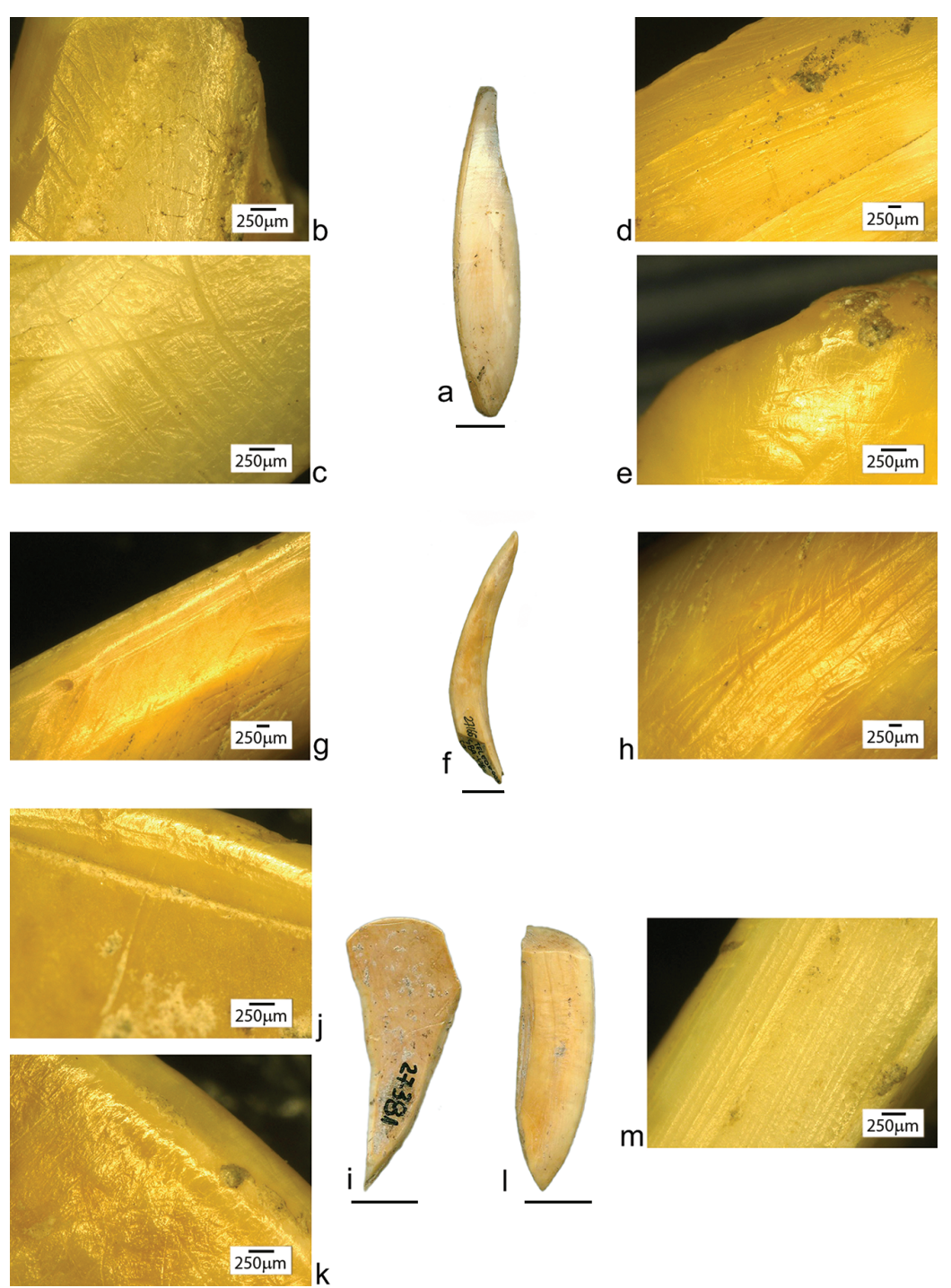

Fig. 3. Teeth artefacts from Măgura-Buduiasca (Dudești culture); a, $\mathbf{f}$ scrapers; b-c abrasion marks; d, h, m scraping marks; g grooving marks; i combination tool; j sawing marks; $k$ use-wear marks; 1 preform.
At Măgura-Buduiasca, five scrapers (Fig. 3.a,f) were obtained from flat blanks extracted by various methods of bipartition: percussion (two items), grooving combined with indirect percussion (one item - Fig. 3.g) and indeterminate (where the shaping operation had removed all previous technological marks - two items). Shaping the tools was acquired by two methods: scraping of the cutting edges only at the distal extremity (three pieces) and scraping of the entire interior surface, followed by abrasion (two pieces - Fig. 3.b-c). When preserved intact (two pieces), the proximal end was regularized by abrasion. Deep scraping on the area of the distal end created a deeper or shallower concavity (Fig. 3.d,h) ending in a thin point (Fig. 3.e), in most cases fractured (four items). It is this concave area that represents the active front (and not the false point). Marks visible on the active front indicate periodic re-sharpening.

A sixth piece is a combination tool with two active ends (Fig. 3.i). The procedures employed for obtaining the flat blank could not be determined as all marks were erased by subsequent scraping of the cutting edges when the 
artefact was shaped. Similar to the items described above, it has a concave active edge at one end - the result of repeated re-sharpening. At the other end, the marks left by the segmentation by sawing (Fig. 3.j) are hardly visible as they were almost erased by the abrasion of the active front. The exterior surface exhibits one area covered by polish with longitudinal scratches (Fig. 3.k), resulting exclusively from use.

The last piece is seemingly a preform for a bevelled-tool (Fig. 3.1). Longitudinal debitage with regularization of the interior surface was the first operation (Fig. 3.m). At one end, oblique abrasion created a chisel-like (bevelled) facet. No use-wear was detected, and thus it is not conclusive whether this was really intended as the active end. Boar canines are also present in funerary contexts, within the necropolis from $\mathrm{Cer}$ nica. All specimens were scrapers. One specimen (Fig. 4.a) was made of a complete tooth, extracted from the mandible. The blank was flat, obtained by bipartition in percussion. The lower surface was regularized by scraping (Fig. 4.b), more visible on the concave edge (Fig. 4.c) representing the active front. In other cases scrapers were made from the distal end of the tooth such as the specimens in graves $81,216,250$ (Fig. 4.d). The cutting procedure could only be determined for one specimen: a combination between grooving and indirect percussion (Fig. 4.e). The other two items had the lower faces regularized by abrasion (Fig. 4.f). The extremities were fractured except for the specimen in grave 250, preserving the proximal extremity regularized by abrasion (Fig. 4.g). On the concave edge there are obvious scraping marks (Fig. 4.h). According to the published data (Comsa, Cantacuzino 2001) such artefacts occurred both in men's and women's graves.

Moreover, one of the scrapers, later transformed into a pendant (Fig. 4.i), was found alongside a male

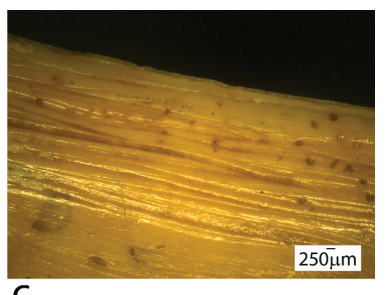

C

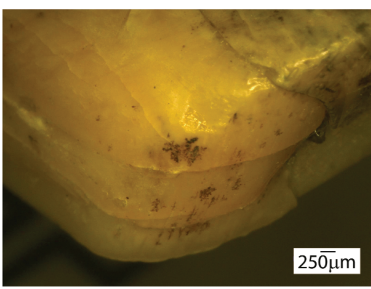

g

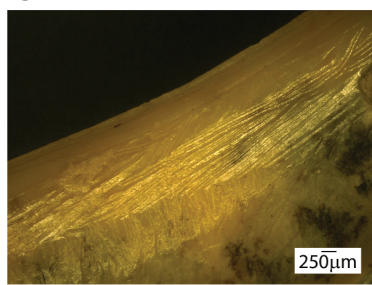

$\mathrm{h}$
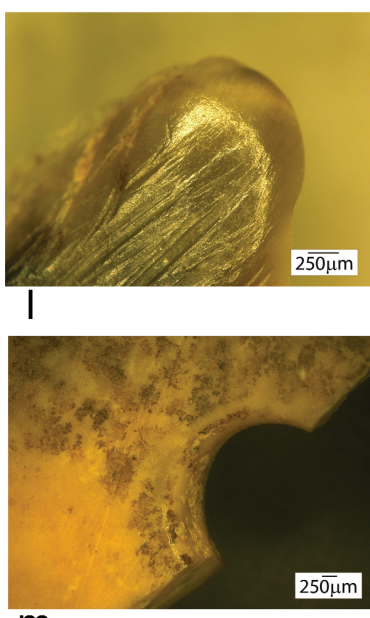

Fig. 4. Teeth artefacts from Cernica necropolis (Final Dudesti/Early Boian culture); a, d, i scrapers; b-c, h, k-l scraping marks; e grooving marks; $\mathrm{f}-\mathrm{g}$, j abrasion marks; $\mathrm{m}$ perforation detail.

individual. The technological procedures observed are similar: the integral abrasion of the lower face (Fig. 4.j); the concave edge was thinned by repeated scraping rendering the active front inefficient (Fig. 4.k-l), and thus the tool was recycled and turned into a pendant. The perforation was carried out by unifacial rotation, initiated from the lower face. The rotation marks are slightly blurred, indicating that the pendant was worn for a while (Fig. 4.m) prior to burial. In grave $\mathrm{M} 241 \mathrm{~B}$, an unmodified boar canine was deposited next to the shoulder blade. The specimen preserved almost the entire length of the tooth, indicating it was extracted from the mandible complete. 


\section{The Gumelnita culture}

Assemblages from four tell-settlements were directly studied by the present authors: Bordușani-Popină, Căscioarele, Hârșova and Vitănești. At two other sites the presence of wild boar implements was noted: Pietrele and Grădiștea Fundeanca.

Two scrapers came from the tell-settlement of Bordușani-Popină One was made from the central area of the tooth (Fig. 5.a). A flat blank was first obtained by longitudinal bipartition, initiated by grooving (Fig. 5.b) on the concave facet and continued by indirect percussion. Subsequently, the concave edge was scraped longitudinally (Fig. 5.c). The active front has not acquired the usual morphology, indicating the artefact had not been used prior to discard. The second piece was made on the proximal end of the canine (Fig. 5.d). The flat blank was obtained by per-
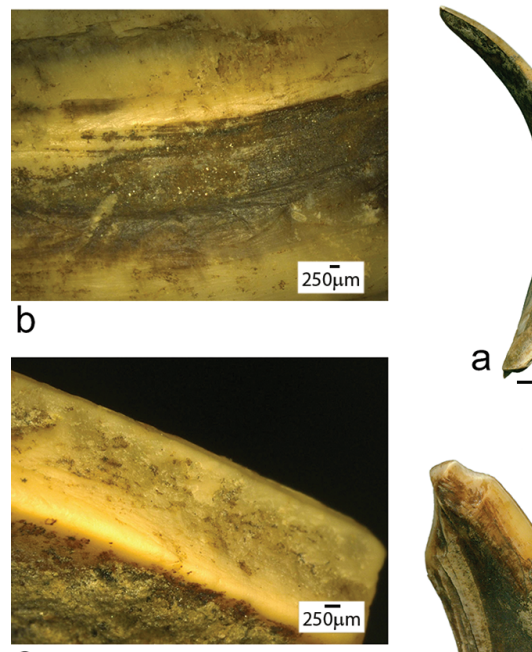

e
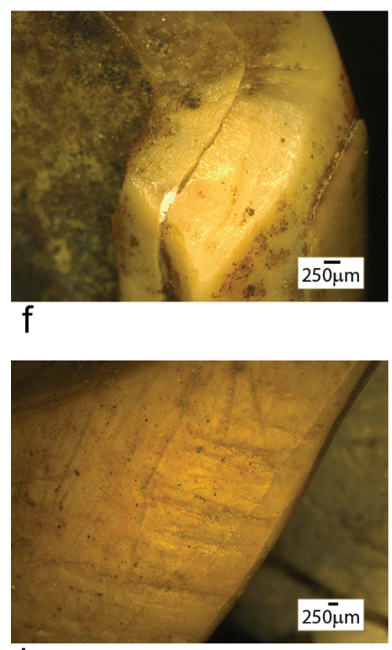

j

Fig. 5. a, d teeth artefacts from Bordușani-Popină (Gumelnița culture); i tooth artefact from Căscioarele (Gumelnița culture); b grooving marks; c, k scraping marks; e unshaped edge; f, j abrasion marks; g-h use-wear area. cussion (Fig. 5.e), and its proximal extremity was shaped by abrasion (Fig. 5.f). Scraping was carried on along the cutting edges to create the desired morphology. The presence of two concavities located bilaterally suggests the existence of two active fronts. Despite the fact the tip of the implement broke at a certain moment in time, the artefact continued to be used, and use-wear formed on the fractured area (Fig. 5.h). There are no re-sharpening marks on the two active fronts, only polish and functional scratches, indicating the implement was used unmodified prior to being discarded (Fig. 5.g).

The Căscioarele assemblage consists of 13 implements, of which 12 are scrapers. Nine were made from the proximal part of the tooth (Fig. 5.i, 6.a) and three from the distal one (Fig. 6.f). All blanks were flat, obtained by longitudinal bipartition in percussion. The cutting edges (Fig. 6.c) and the proximal end were adjusted by abrasion (Figs. 5.j, 6.b). The deep concavity exhibiting scraping marks (Figs. 5.k, 6.d,e) located towards the distal end is associated with a point that was intentionally created and not the result of use. On most of these artefacts, the tip of the point broke during use. Six specimens were intensely used, until the active front which had been repeatedly shaped by scraping was exhausted, and the items became very thin in this area (Figs. 5.i, 6.a), and further use would have led to their breaking.

Two implements (made on the distal end of the tool) are extremely narrow (Fig. 6.f); the concave edge had barely formed but reached its maximum depth (Fig. 6.g-h). They were also used as scrapers, their particular morphology possibly pointing towards a different type of action or their use on a different type of material.

The thirteenth piece was recycled and transformed into a pendant (Fig. 6.i). Originally a scraper obtained in the same way as the other 12 (on a flat blank, obtain- 
ed by longitudinal percussion; shaping by abrasion applied both to the cutting edges and the proximal end; active front with a deep concavity located on an area of narrow breadth; broken tip), when it became unusable, the initial tool was perforated by unifacial rotation initiated from the interior face. It had not even been re-sharpened after its last use, as the scraping marks are blurred (Fig. 6.j). The rotation marks inside the perforation are still visible but blurred, suggesting its long use as a pendant (Fig. 6.k).

The tell-settlement of Hârșova yielded four implements: two preforms and two finished tools. A fractured preform was extracted from the central area of the tooth. The tooth was split longitudinally by percussion. The edges were shaped by scraping. The functional edge had not been created, suggesting the item was still in the process of modification. A second preform was made from the proximal area (Fig. 7.a). Shaping of the distal end by longitudinal scraping along the edge was started, but not finalized (Fig. 7.b). Irregular scraping took place at the proximal end, both on the interior and the exterior faces. Two cuts made by sawing (Fig. 7.c) are visible on the exterior face, but further observations are not possible given the fractured state of the artefact.

Both finished pieces were made from the proximal area of the tooth. In the first case, the tooth was cut longitudinally but the identification of the procedure was rendered impossible by the abrasion of the cutting edges. The proximal end was cut transversally by sawing as shown by microscopic marks, despite the extremely rigorous shaping by abrasion of the area. The concave edge was scraped on the mesodistal area creating the active front.

At the second implement (Fig. 7.d), the fracture edges and the inferior face were fully abraded (Fig. 7.e). At the distal end, the inferior face and the concave edge were rigorously shaped by scraping (Fig. 7.f). The tip broke some- time during use, but the area of the fracture was abraded and the item remained in use. The concavity of the active front is deep, narrowing the width of the artefact in this area.

The Gumelnita B1 level from the settlement of $V i$ tănești yielded three artefacts, a preform and two finished implements, probably combination tools. Pieces made from this raw material seem to be present in the A2 level of the same site (Torcică 2017. Fig. 62) but we did not have the opportunity to analyse the archaeological material. The median area of the tooth was used for the preform, detached from the mandible by percussion. Longitudinal bipartition was achieved by indirect percussion. The concave edge was adjusted by abrasion. There are no signs of use-wear or scraping.

One finished (and used) piece was manufactured from the proximal area of the tooth, indicating the
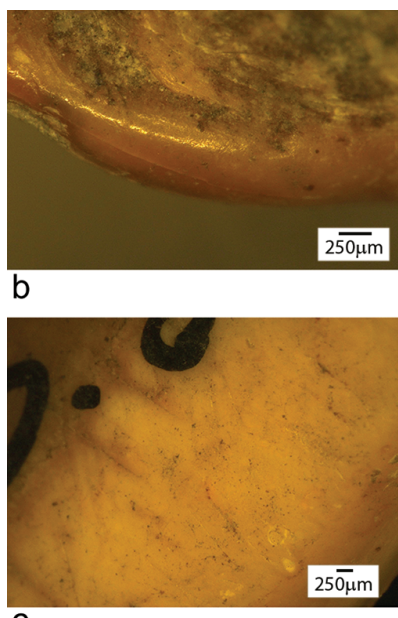

C

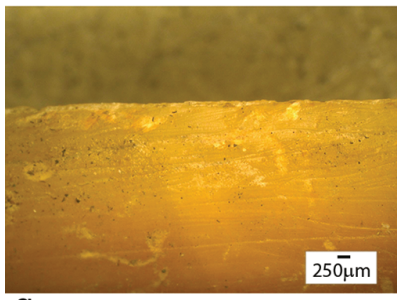

g

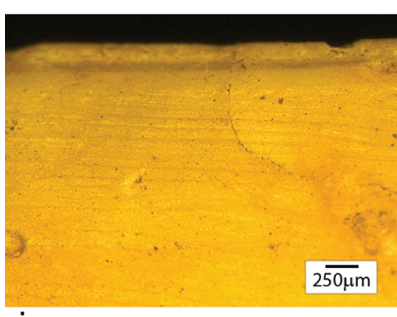

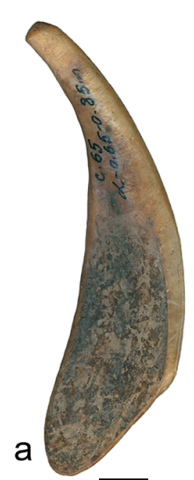

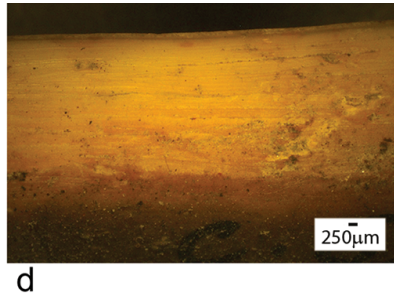

d
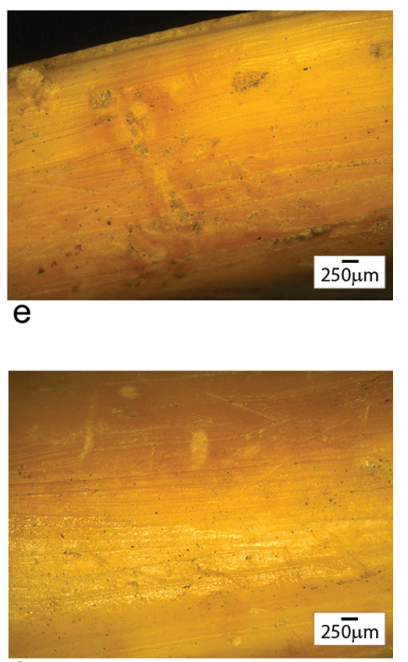

$\mathrm{h}$

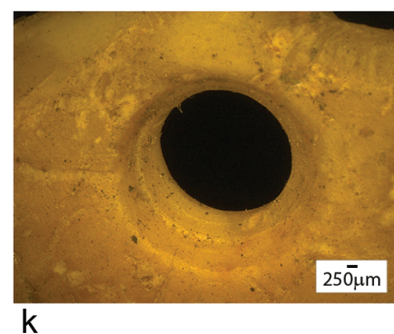

Fig. 6. a, f, i teeth artefacts from Căscioarele (Gumelnița culture); b-c abrasion marks; d-e, g-h, j scraping marks; k perforation detail. 
tooth was extracted complete. The blank was obtained by percussion, followed by scraping to regularize the concave edge. The rest of the cutting edge remained unshaped. The concave edge was not the only active front, the fractured distal extremity seemingly had a bevelled morphology. The small area still preserved shows strong wear, with rounding of the surface and the erasure of technological marks. The second item also had two active fronts (Fig. 7.g). The procedure for longitudinal bipartition remains obscure, as the interior face was rigorously abraded. Transversal segmentation was performed by sawing (Fig. 7.h). Atypically, scraping marks on the convex edge indicate it to be the functional edge. It acquired an oblique rectilinear morphology. The distal end, shaped by abrasion, also has a convex morphology. The erasure of the abrasion marks towards the distal extremity and the smoothness of this area suggest the distal end might have also been active (Fig. 7.i). No re-sharpening of the tip is visible.

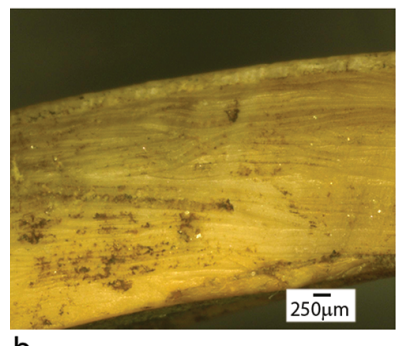

b

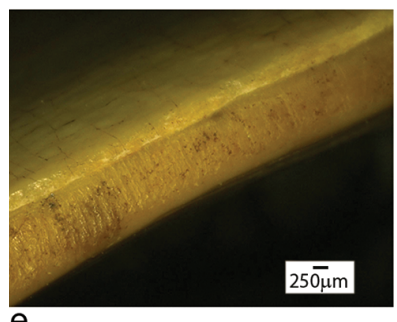

e

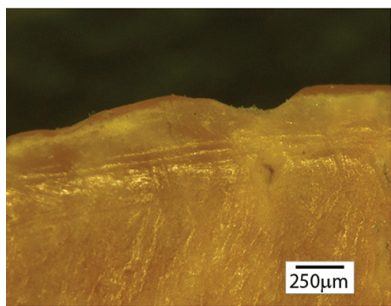

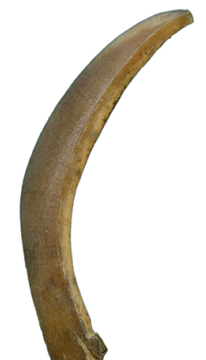

a
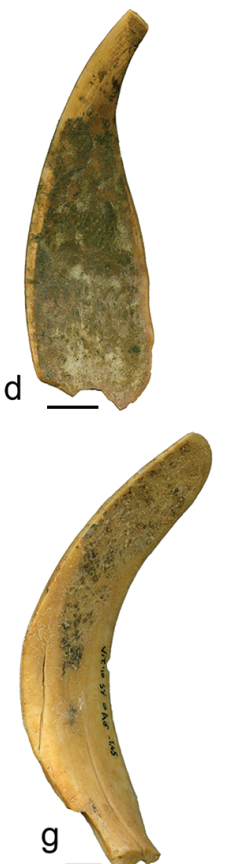
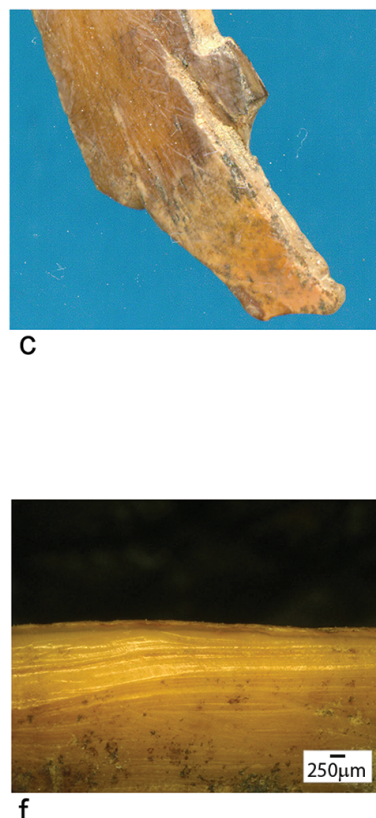

C f

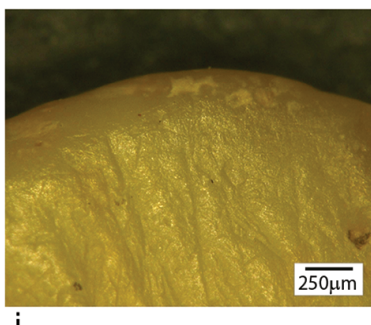

i

\section{The Cucuteni culture}

The assemblage studied directly by the present authors originated from Drăguseni (Neamt County) and comprises 10 pieces: two blanks and eight finished implements.

The two flat blanks were obtained by bipartition by percussion. The central area of the tusk was used for their manufacture, between the proximal end and the tip, an area partially hollow inside.

Scrapers were the only typological category present. They were all manufactured on flat blanks obtained by bipartition by percussion retaining the entire length of the tooth $(n=1)$, from the middle area of the tusk $(n=4)$, and the tip $(n=2)$. At two specimens the debitage edges and the inferior side $(\mathrm{n}=2)$ were shaped by abrasion (Fig. 8.a-b), while at two other specimens only the debitage edges $(n=2)$ were $a b-$ raded. In one case the debitage edge was adjusted by scraping. The proximal end (preserved in two cases) was created by abrasion. The opposite end was arranged by scraping (Fig. 8.c). The scrapers display little use-wear, given the fact the active front had not yet acquired the concave morphology. However, there are visible re-sharpening marks.

One scraper was made on the entire length of the tooth (Fig. 8.d). The blank was obtained by bipartition by percussion, with the abrasion of the inferior face (Fig. 8.e-f). The active area was created by scraping (Fig. 8.g) towards the proximal part of the tooth. The shallow concavity that had formed indicates the implement was used for only a short while.

One artefact (a double point) has two functional areas (Fig. 8.h). The blank is flat, extracted from the distal area of the tooth. The bipartition was performed by percussion, and the inferior face was abraded (Fig. 8.i). Two concave active fronts are visible, most likely used alternately. The piece shows extensive use-wear at the active ends, and both ex- 
tremities probably fractured during use. Light scraping marks (Fig. 8.j) indicate the piece was likely never sharpened before being discarded.

\section{The experimental program}

Our experiment involved both working wild boar canines and using the resulting tools. The presence of archaeological artefacts made from the proximal end of the tooth shows that at least some were extracted complete from the mandible. By testing different methods, we observed that in order to achieve this and not damage the tooth, the best method was to carefully break the mandible around the tooth. We also identified the main reason for the exclusive use of flat blanks: following dehydration, canines extracted from the mandible tend to crack longitudinally, starting from their proximal part (Fig. 9.a). The crack facilitates obtaining two similar flat blanks by striking a few blows by percussion. This has been
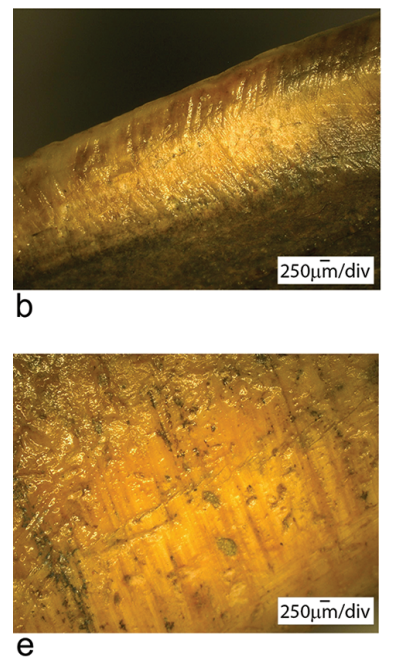

a
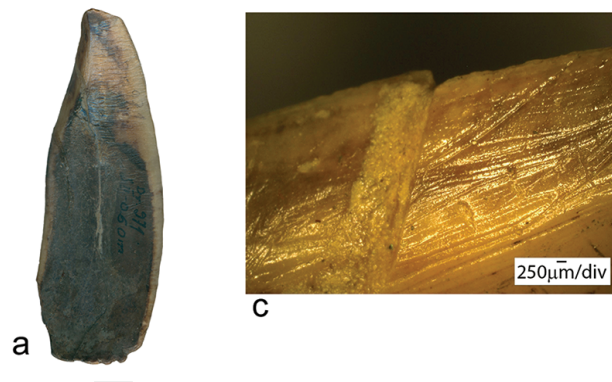

C
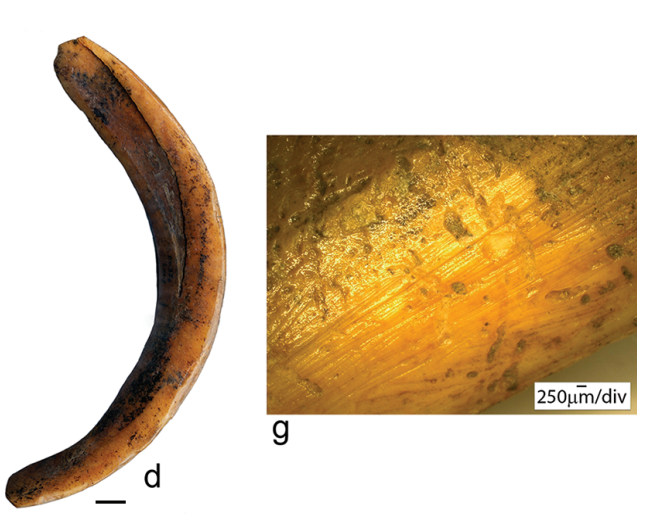

g

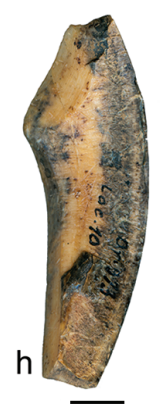

highlighted previously by other studies (Maigrot 2005; Marquebielle 2014).

For the debitage, both procedures observed on the archaeological specimens were tested: percussion and combined grooving + indirect percussion. Percussion: the natural crack of the tooth was hit with a hammer a few times, followed by detachment by bending (Fig. 9.b-c). Most likely, bipartition by grooving was used for fresher teeth, to facilitate the propagation of the crack along the entire length of the tooth. Using a burin, a groove was initiated by unidirectional movement of the tool (Fig. 9.d). Several attempts showed that no great depth or length (e.g., along the entire tooth) were necessary (Fig. 9.f-g). The entire bipartition took $c .5$ minutes. The two blanks thus marked were detached using a bone pointed tool (prepared beforehand) and a stone hammer. The tip of the bone tool was fixed in the groove and hit with the hammer; if necessary the same action was repeated along the groove. Generally, the crack spread along the tooth after only a few blows. This entire procedure took only a few seconds (Fig. 9.e).

The obtained blanks were then transformed into (1) bevelled tools and (2) scrapers, as with the archaeological specimens.

Bevelled tools. The active bevelled front was obtained by a combination of unifacial sawing and bending. Segmentation was achieved using a lithic implement with a sharp edge, employed in a bidirectional movement (Fig. 10.a). When the cut was deep enough (depending on the thickness of the tooth), bending was applied (Fig. 10.b). Our experiments indicated that when bending took place prematurely, accidents occurred damaging the morphology of the active front. This procedure lasted $c .10 \mathrm{~min}$.

The active front thus obtained had a V-shaped section morphology, and displayed long, deep and regular microscopic scratches (Fig. 10.c). It was then shap-

Fig. 8. a, d, h teeth artefacts from Drăgusseni (Cucuteni culture); b, e-f, i abrasion marks; c, g, j scraping marks. 
ed to acquire the bevelled morphology. The procedure was performed by transverse scraping of the active end, using a flint blade (Fig. 10.d). In about one minute, the surface became regular, with long and irregular scratches (Fig. 10.e-f).

The experimentally obtained implements were then used to remove wood bark (Fig. 11.a). Tools were highly efficient for approx. 10 minutes, then the active front became blunt, acquiring a strong polish. Re-sharpening by transverse scraping was applied (Fig. 11.b). After $c .40$ minutes of use in all, the active front changed from a rectilinear (Fig. 11.c) to a concave morphology (Fig. 11.d), suggesting that the different morphologies observed on the archaeological artefacts were not caused by different ma-

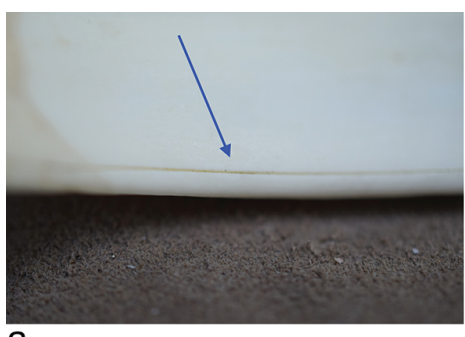

a
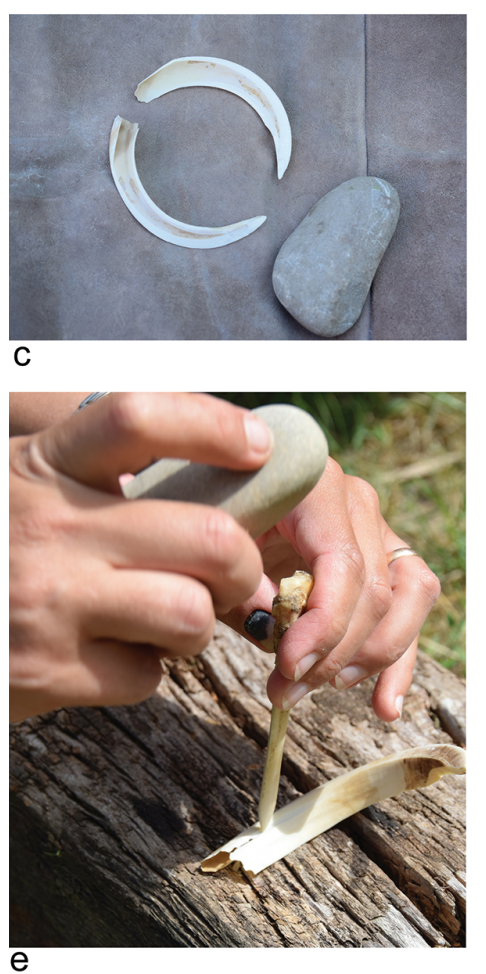

$\mathrm{e}$

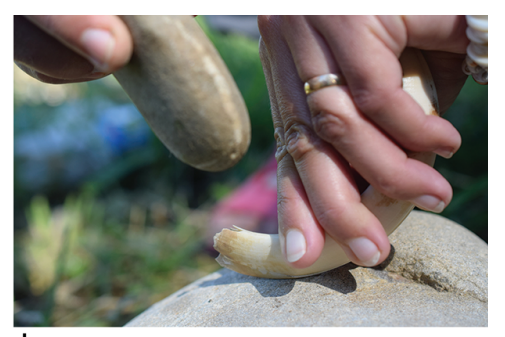

$\mathrm{b}$

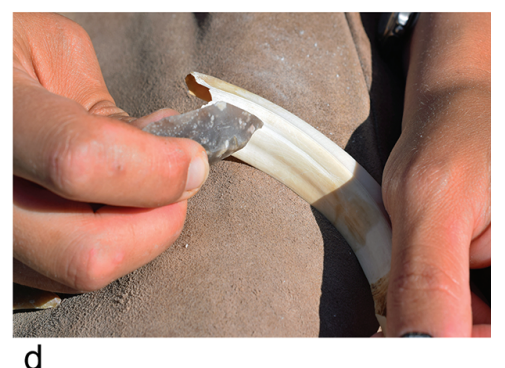

d

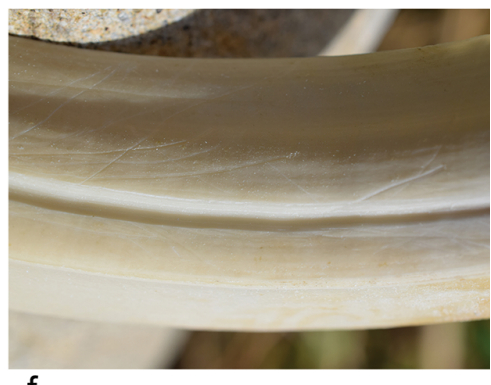

f

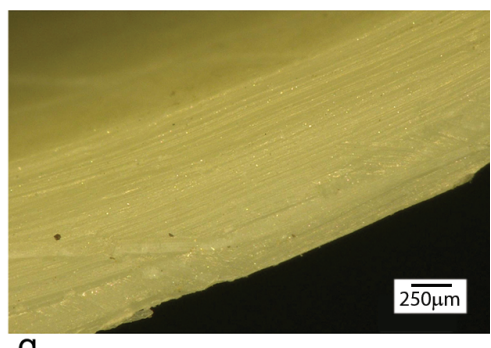

g
Fig. 9. Experimental debitage operation: a natural crack; b bipartition by percussion; c blanks; d-e bipartition by grooving and indirect percussion; f-g groove details. nufacturing processes, but by variable degrees of use. A more concave morphology suggests longer usage. No use-wear marks were left on the active front, having been eliminated by the periodic resharpening.

Scrapers. Segmentation by unifacial sawing, followed by bending were the initial procedures (Fig. 12.a). Segmentation was applied obliquely to the axis of the tooth. To shape the tool, scraping along the cutting edges (Fig. 12.b-c), combined with abrasion (Fig. 12.d) on one of the sides (as identified at the archaeological pieces) took place; the active front was regularized by longitudinal scraping. This entire procedure was completed in 5 minutes. The scrapers thus obtained (Fig. 12.e) were used for stripping bark for 40 minutes. Since only the central part of the active front actually touched the wood, the wear developed along this surface. Moreover, being re-sharpened every ten minutes, a concavity appeared in the central area. It evolved gradually (Fig. 12.f) according to the degree of wear, hence the differing morphologies of the active fronts on the archaeological scrapers.

\section{Discussion}

\section{Acquisition of raw material}

Wild boars live in groups of 10-20 individuals, consisting of females and sub-adults, led by a female ( $L e$ $d u c$ et al. 2015). Males, on the other hand, are solitary most of the time, the separation from the group occurring between 11 and 16 months (Nivois et al. 2014). Two types of hunting expeditions can thus be distinguished at the prehistoric communities, based on their goal: (1) for the group of females and sub-adults (allowing the capture of several individuals) and (2) for the solitary male (allowing the capture of a single specimen). The two implied different hunting strategies and in the second case it could have turned more dangerous (although chasing a mother defending her young might also prove lethal). The latter expedition type aimed at collecting tusks for tools (in addition to procuring meat), 


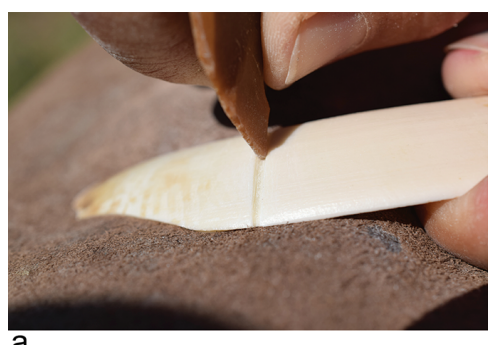

$\bar{a}$
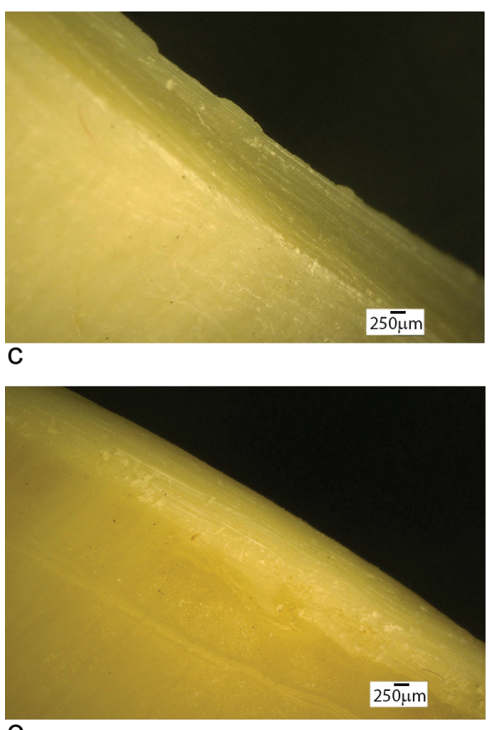

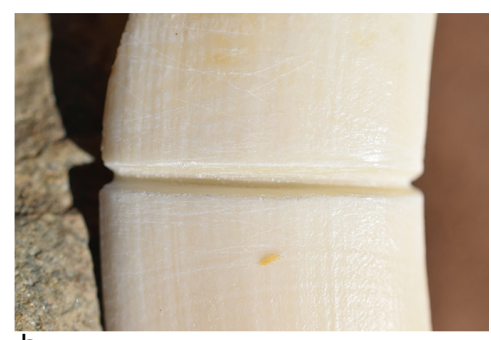

$\mathrm{b}$

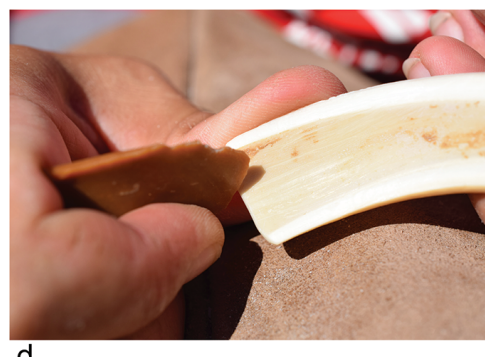

d

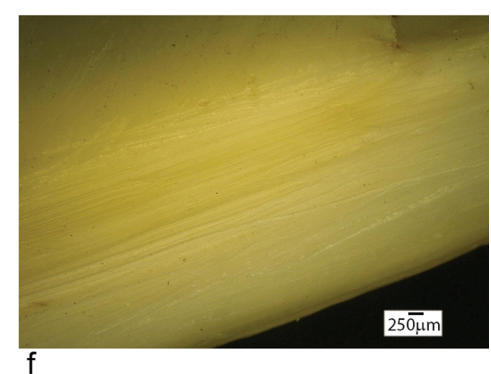

Fig. 10. Experimental shaping operation: a sawing procedure; b-c groove details; d shaping of the active end; e-f active end details.

Ruginoasa and Scânteia in the Cucuteni area). According to the published illustration, the Pietrele canine fragment preserves a thin active end with a deep concavity (indicating a former scraper), but is also perforated. Similar artefacts came from earlier Hamangia (Cheia, Constanta County; Voinea et al. 2014) and Precucuteni contexts (Târgu-Frumos, Iași County; Iatcu et al. 2016). It is our belief that such artefacts were not meant initially to be ornaments, as such pendants (originating both from occupation layers and funerary contexts) do not show any traces of scraping/specific active edges for scrapers as we have identified at the items discussed. This indicates a prior stage in the artefact's biography, that of a functional tool. Their transformation does not seem to be a systematic process, though.

Wild boar appliqués or pendants, manufactured as such, were recorded both in funerary contexts at Cernica (Mărgărit, Vintilă 2015) and Chiras only adult males could provide canines as large as those found in the archaeological collections. The larger/older the animal, the longer the canines.

Hunting might thus have been a selective choice between the mere procurement of meat and the procurement of a certain type of raw material (tusk). A certain limitation of the available tusk is also suggested by the use of complete canines and the continuous re-sharpening of the tools obtained. Moreover, many of the finished items are made on thin blanks, which means they derive from the base of the tooth, indicating the tooth was extracted from the mandible undamaged and complete. The acquisition of the raw material in the case of the wild boar tooth thus requires an additional effort related to both the hunting of the animal and the obtaining of the raw material.

Also indicative of possible constraints regarding the availability of tusk, is the transformation of exhausted tools into pendants. During the Chalcolithic this occurred both in funerary contexts (at the Cernica necropolis and Pietrele; Hansen et al. 2011.Abb. 22) and in settlements (Căscioarele, Grădiștea-Fundeanca, Gumelnita in the Gumelnita culture, and Bodești-Frumușica, Bonțești, Fulgeriș-La trei cireși, Poienești,
nogi-Suvita Iorgulescu (Mărgărit, Dimache 2019) and in the occupation layers at Măgura-Buduiasca (Dudești level; Mărgărit et al. 2016), Radovanu (Mărgărit et al. 2014), Vidra (Mărgărit, Vintilă 2018), Târgu Frumos (Ursulescu et al. 2006), Fulgeriș (Iatcu et al. 2016), Scânteia (Mantu, Turcanu 1999) and Drăgușeni (Marinescu-Bîlcu, Bolomey 2000). Those pieces had been worn as ornaments, and display

\section{The scarcity of wild boar implements in Neo- lithic/Chalcolithic assemblages}

Although apparently less frequent than during the Mesolithic, artefacts made of wild boar canines are nevertheless present in most Neolithic and Chalcolithic cultures at the Lower Danube. The Mesolithic 'abundance' is in fact restricted to the area of the Iron Gates, with other Mesolithic/Tardenoisian sites yielding no implements other than lithics. The assemblages we studied clearly indicated that the technological knowledge of tool-making does not disappear, despite the fact they are no longer essential in the toolkits of the community members.

Without getting into much detail, our research into previous publications suggests that the scarcity of use-wear. 
the Neolithic/Chalcolithic sites with finds of wild boar implements may be the result of a series of factors: the manner of excavation (no wet/dry sieving employed), the size of the areas actually excavated at a particular site, their selection as mere faunal remains (which often remained unpublished) and their lack of inclusion among the archaeological materials selected for brief excavation reports. It is noteworthy that most of the artefacts we traced (and there are probably more) came from earlier publications from the 1930s and 1940s when field reports were more detailed and rigorous. Undoubtedly, such finds occurred at those sites in later excavations but were not reported.

Other than the excavation and publication bias, there is also the question of the intensity of the hunting practices among these later prehistoric communities, and the availability of wild boar in various areas during prehistoric times.

The NMI of wild species from Early Neolithic Măgura-Buduiasca amounts to $c$. $55 \%$ of the faunal remains. Wild boar holds second place (after deer) with a hunting preference for adult individuals. During the Dudești occupation of the same site, domestic animals prevail (76.6\%), and wild boar falls fourth among the wild species (after deer, aurochs and roebuck). The frequency of wild species rises again during the Gumelnita culture: at Căscioarele (level B1) they amount to $84.1 \%$ with a quantitatively significant number of wild boar remains at si-
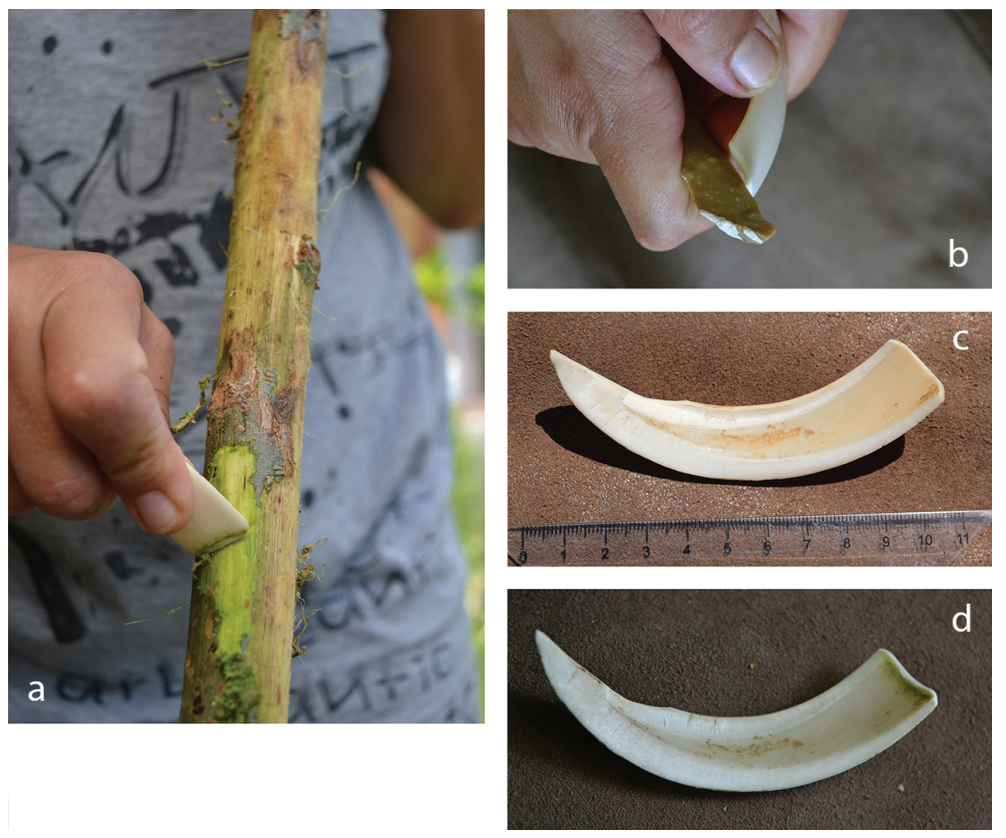

Fig. 11. Use of tooth bevelled tool: a wood bark removal; b re-sharpening of the active end; c unused bevelled tool; $\mathrm{d}$ used bevelled tool. tes such as Gumelnita and Hârșova (Bălăsescu et al. $2005 a$; 2005b). In contrast, at the sites in the Teleorman Valley wild boar does not exceed $4 \%$ throughout the Neolithic, but reaches 14\% during the Chalcolithic Gumelnita A2 phase (Bălășescu, Mărgărit 2014). Important variations in the percentages of the hunted species were noted during different chronological stages. Still, the number of tools made of wild boar canines stays constantly low despite all these variations recorded in the faunal assemblages.

\section{The technological analysis of wild boar im- plements}

The typology observed is poor: wild boar teeth were used mostly to manufacture scrapers with different morphologies, followed by a much smaller number of combination tools and bevelled implements. Within these three categories there are several subtypes resulting from variations/combinations in the morphology of the active end. It is noteworthy the prevalence of the longitudinal debitage, favoured by the mechanical characteristic of the material. Being hollow inside and triangular in section, longitudinal natural fracture lines occur along the tooth. Following the death of the animal/extraction of the tooth, the tusk tends to crack, especially in dry environments (see the Experimental program above).

Productivity appears to be high in these prehistoric assemblages and little of the tooth was left unused. Longitudinal bipartition allows the extraction of two similar blanks, both to be transformed into finished items. The main technique was longitudinal splitting by percussion, combined at times with grooving and indirect percussion. Transversal debitage took place by direct percussion and, more rarely, by sawing.

Surface modification was almost universally accomplished by scraping, with abrasion used more rarely. These techniques were combined on different artefacts, in order to shape the sides of the blank. Alternatively, scraping was used for the development of the active front.

A comparison between the studied Mesolithic and Neolithic/Chalcolithic assemblages shows continuity both typologically and technologically. Scrapers were predominant both the Mesolithic and Neolithic/Chalcolithic 


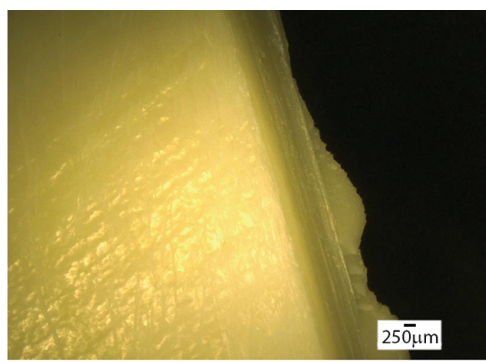

a

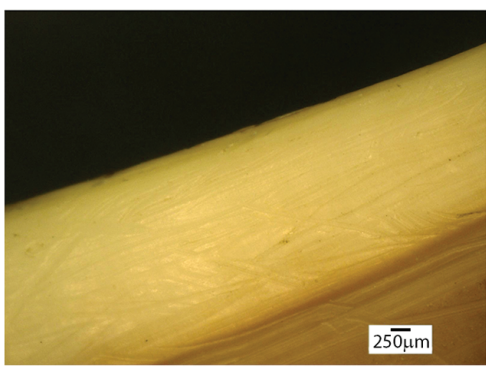

C

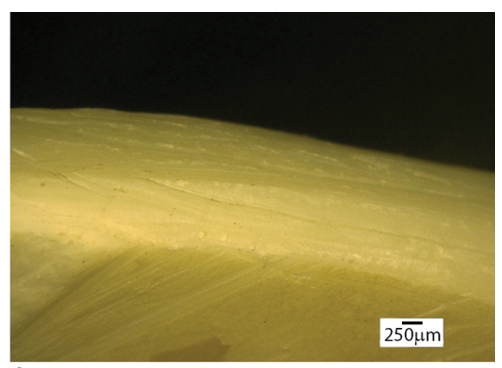

b
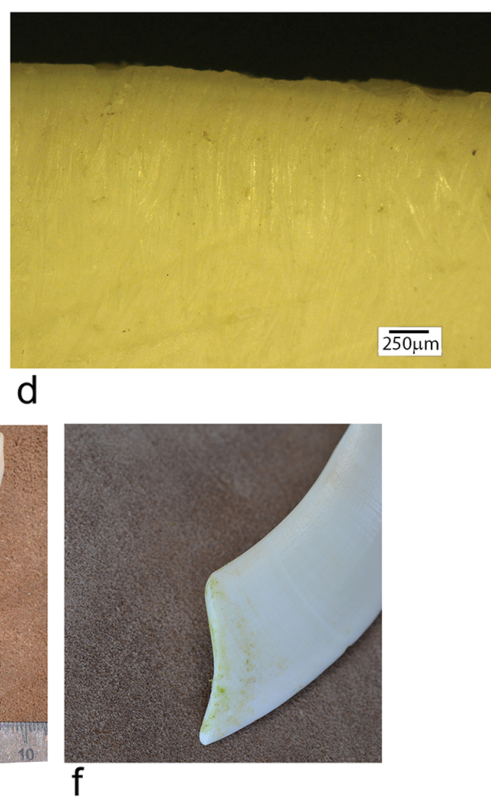

e

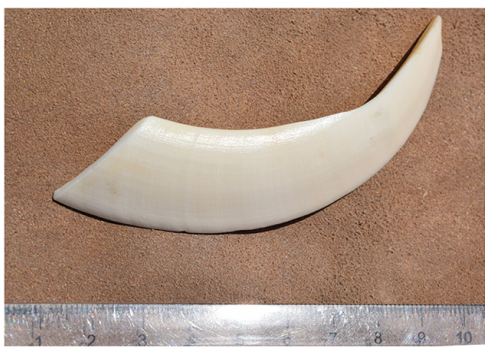

Fig. 12. Processing and use of tooth scraper: a sawing marks; b-c scraping marks; d abrasion marks; e unused scraper; f used scraper.

assemblages, followed by bevelled and combination tools. During all periods, the prevalence of longitudinal exploitation of the tooth was noted. However, during the Mesolithic, volume blanks were also used and only flat blanks were observed during later prehistory. The main technique used for longitudinal debitage remained percussion, and sometimes also a combination of grooving and percussion. Surface modification was almost universally accomplished by scraping, with abrasion used more rarely throughout the entire earlier prehistory.

\section{Functionality}

Over time, the terminology employed for the tools made of wild boar canines varied, as did the functionality assigned to them. Initially, starting strictly from their morphology, a double function was suggested, associating their use in cutting and drilling actions, and the tools were thus called perçoirs with sharp edges (Barbaza 1989). Éva David (2000) called them chisels given the lateral morphology resembling that of a chisel flank, used for scraping while the tip (when existing) was used for grooving, like a burin.
Romanian terminology followed the trends of the international one. Earlier publications illustrate points (in Romanian 'vârf'), tools for pottery decoration/smoothening (in Romanian 'netezitor'), etc. The functional interpretation of the artefacts was further complicated in many cases by the presence of the false points (see above, in the section on morphology), seen as the active parts, and thus those pieces were erroneously interpreted by non-specialists as piercers/perçoirs -'străpungătoa$r e$ '. The perforations on some of the tusk artefacts saw them automatically catalogued as pendants/ adornments ('pandantive'), and thus the previous biography of the object was completely disregarded.

More recent publications, based mainly on comparisons with ethnographic data collected from Indonesia, indicate their use in scraping wood and removing bark (Maigrot 2001; 2005; Legrand, Sidéra 2007; Sidéra 2000; 2008; 2012). Our own experiments pointed towards the same conclusion. Moreover, experimental studies related to the archaeological materials of northwestern Russia and northeastern Belarus ( $4^{\text {th }}$ $2^{\text {nd }}$ mill. BC) have proven that the pieces of wild boar canines were used for the working of wood and bark, skin, and the drilling of abrasive materials (Malyutina, Charniauski 2021). The very fresh aspect of the scraping marks existing on some artefacts encouraged us to suggest the periodic restoration of the active front. This is also confirmed by the ethnographic studies of Patricia Anne Chiquet et al. (1997).

\section{Conclusion}

The experimental examples presented above confirm the high efficiency of these tools in wood processing activities. Boar canine scrapers proved resistant enough not to break during use. The tools' endurance was proven experimentally, and their use was possible until the active front was exhausted with no possibility of further re-sharpening. As shown in some cases, when the active front was inefficient, the pieces were turned into pendants. A 
second important conclusion of our experiments was that all tools had the same functionality regardless of the morphology of the active front, and the items were efficient in the same wood processing actions. Additionally, there was a permanent concern for maintaining an effective active front by periodically re-shaping it. Few sites have yielded waste products/blanks, so no definite conclusion can be reached regarding their place of manufacture, but the site seems to be the place for their use and discarding.

In addition, finished items are generally fractured and significantly more numerous in relation to the by-products of the operating chain. The fact that the blanks are almost absent means that there was no stock of blanks to be processed as needed. The tooth was probably completely transformed into the finished objects after extraction.

$$
\text { ACKNOWLEDGEMENTS }
$$

This work was supported by a grant of the Romanian Ministry of Education and Research, CCCDI - UEFISCDI, project number PN-III-P2-2.1-PED-2019-1279, within PNCDI III and with financial support from the Recurring Donors Fund of the Romanian Academy managed by the Patrimoniu Foundation (project no. GAR-UM-2019-II-2.1-1/15.10.2019). We would like to thank Pavel Mirea for granting us access to the collections of the Teleorman County Museum and to Radu-Alexandru Dragoman to the archaeological assemblage of Căscioarele-Ostrovel ("Vasile Pârvan" Institute of Archaeology, Romanian Academy).

\section{References}

Albarella U., Dobney K., and Rowley-Conwy P. 2006. The Domestication of the Pig (Sus scrofa). New Challenges and Approaches. In M. A. Zeder, D. G. Bradley, E. Emshwiller, and B. D. Smith (eds.), Documenting deomestication. New genetic and archaeological paradigms. University of California Press. Berkley and Los Angeles: 209-228.

Barbaza M. 1989. Cultures et société au Paléolithique terminal, au Mésolithique et au début du Néolithique ancien dans le sud-ouest de l'Europe. Mémoire d'habilitation à diriger des recherches. Toulouse le Mirail University. Toulouse.

Bălăsescu A., Mărgărit M. 2014. Domestic versus wild during the Neolithic in the Teleorman Valley/Domestic versus sălbatic în neoliticul de pe valea Teleormanului. In M. Mărgărit, G. Le Dosseur, and A. Averbouh (eds.), An overview of the exploitation of hard animal materials during the Neolithic and Chalcolithic/O privire asupra exploatării materiilor dure animale de-a lungul neoliticului și calcoliticului. Cetatea de Scaun. Târgoviște: 71-90.

Bălășescu A., Radu V., and Moise D. 2005a. Omul si mediul animal între mileniile VII-IV î.e.n. la Dunărea de Jos. Cetatea de Scaun. Târgoviste.

Bălăsescu A., Moise D., and Radu V. 2005b. The palaeoeconomy of Gumelnita communities on the territory. Cultură și civilizație la Dunărea de Jos XXII: 167-206.

Bejenaru L., Ursulescu N., Cotiugă V., and Stanc S. 2013. Manufacture and use of boar tusks at Târgu Frumos (Iași County, Romania): Chalcolithic, Precucuteni culture. Po- ster presentation at the $9^{\text {th }}$ meeting of Worked Bone Research Group, Henan Administration of Cultural Heritage, and the Henan Provincial Institute of Cultural Relics and Archaeology in Zhengzhou City, Henan province, China. 14-20 April 2013.

Beldiman C. 2007. Industria materiilor prime animale în preistoria României. Resurse naturale, comunități umane și tehnologie din Paleoliticul superior până în Neoliticul timpuriu. Studii de Preistorie. Supplementum 2. Asociatia Română de Arheologie. Editura Pro Universitaria. București.

Beldiman C., Sztancs D.-M. 2009. Industria materiilor dure animale aparținând culturii Starčevo-Criș descoperită în așezarea de la Măgura 'Buduiasca-Boldul lui Moș Ivănuș', jud. Teleorman. Considerații asupra repertoriului tipologic. Buletinul Muzeului Judetean Teleorman. Seria Arheologie 1: 31-54.

2013. The osseous artefacts of the Starčevo-Criş culture in Romania. An overview. In A. Comșa, C. Bonsall, and L. Nikolova (eds.), Facets of the Past. The Challenge of the Balkan Neo-Eneolithic. Proceedings of the International Symposium Celebrating the $85^{\text {th }}$ Birth Anniversary of Eugen Comșa, 6-12 october 2008. Academy Publishing House. București: 106-133.

Beldiman C., Sztancs D.-M., and Cornel I. 2012. Artefacte din materii dure animale in colecția Muzeului de Istorie Galati. Eneolitic/Osseous Materials Artefacts in the Collection of History Museum Galat,i. Aneolithic. Editura Mega. Cluj Napoca. 
Bem C. 2001. Noi propuneri pentru o schiț̆ cronologică a eneoliticului românesc. Pontica XXXIII-XXXIV: 25-121.

Berciu D. 1956. Cercetări și descoperiri arheologice în regiunea București. Materiale și cercetări arheologice II: 491-562.

Boghian D., Enea S. C., Ignătescu S., Bejenaru L., and Stanc S. M. 2014. Comunitățile cucuteniene din zona Târgului Frumos. Cercetări interdisciplinare în siturile de la Costești și Giurgești. Editura Universității "Alexandru Ioan Cuza". Iași: 51-60.

Boroneant A. 2012. Aspecte ale tranzitiei de la mezolitic la neoliticul timpuriu în zona Porțile de Fier. Mega. Cluj-Napoca.

Cantacuzino Gh., Morintz S. 1968. Descoperirile arheologice de la Cernica și importanța lor pentru cunoașterea vechilor culturi din țara noastră. București. Materiale de Istorie și Muzeografie. Muzeul Municipiului București VI: 7-26.

Chiquet P. A., Rachez E., and Pétrequin P. 1997. Les défenses de sanglier. In Les sites littoraux néolithiques de Clairvaux-les-Lacs et de Chalain (Jura), III: Chalain station 3, 3200-2900 av. J.-C. Archéologie et culture matérielle. Éditions de la Maison des sciences de l'homme. Paris: 511-521.

Christescu V. 1933. Les stations préhistoriques de Vădastra. Dacia III-IV: 167-225.

Comșa E., Cantacuzino Gh. 2001. Necropola neolitică de la Cernica. Editura Academiei Române. București.

David É. 2000. L'industrie en matières dures animales des sites mésolithiques de la Baume d'ogens et de Birsmatten Basisgrotte (Suisse): résultats de l'étude technologique et comparaisons. Cahiers d'Archéologie Romande 81: 79-101.

Dumitrescu H. 1933a. Rapport sur les sondajes de Grădistea-Fundeanca. Dacia III-IV: 150-156.

1933b. La station préhistorique de Ruginoasa. Dacia III-IV: 56-87.

Dumitrescu V. 1924. Découvertes de Gumelnița. Dacia I: 325-342.

1925. Fouilles de Gumelnita. Dacia II: 29-103.

1933. La station préhistorique de Bonțești. Dacia IIIIV: $88-114$.

1965. Principalele rezultate ale primelor două campanii de săpături din așezarea neolitică târzie de la Căscioa- rele. Studii si Cercetări de Istorie Veche 16(2): $215-$ 237.

1986. Stratigrafia așezării tell de pe Ostrovul de la Căscioarele. Cultură și Civilizație la Dunărea de Jos 2: 73-81.

Hansen S., Toderaș M., Reingruber A., Nowacki D., Norgaard H., Spânu D., and Wunderlich J. 2011. Die kupferzeitliche Siedlung Pietrele an der Unteren Donau. Bericht über die Ausgrabungen und geomorphologischen Untersuchungen im Sommer 2010. Eurasia Antiqua 17: 45-120.

Iatcu I., Turcanu S., Solca L., and Bejenaru L. 2016. De la natură la cultură: arta prelucrării osului și cornului. Catalog de expoziție. Editura Palatul Culturii. Iași.

Konjević D., Kierdorf U., Verstraete F. J. M., Janicki Z., Slavica A., Keros T., and Severin K. 2004. Malformation of the permanent maxillary canine after dental infraction in a wild boar (Sus scrofa L.). Journal of Zoo and Wildlife Medicine 35(3): 403-405. https://doi.org/10.1638/03-101

Lazarovici C. M, Lazarovici Gh. 2012. Ruginoasa-Dealul Drăghici. Monografie arheologică. Bibliotheca Archaeologica Moldaviae XX. Editura "Karl A. Romstorfer". Suceava.

Lazarovici C-M., Babeș M. 2015. Poienești - Așezări preistorice. Volume 22. Bibliotheca Archaeologica Moldaviae. Editura Karl Ramstorfer. Iași.

Leduc C., Bridault A., and Cupillard Ch. 2015. Wild boar (Sus scrofa scrofa) hunting and exploitation strategies during the Mesolithic at Les Cabônes (Ranchot Jura, France), layer 3. Journal of Archaeological Science: Reports 2: 473-484. https://doi.org/10.1016/j.jasrep.2015.05.010

Legrand A., Sidéra I. 2007. Methods, Means, and Results When Studying European Bone Industry. In C. Gate, R. Walker (eds.), Bones as tools: current methods and interpretations in worked bone studies. Congrès de la SAA, Montréal, Avril 2004. BAR International Series 1622. Archaeopress. Oxford: 291-304.

Luca S. A., El Susi G. 1989. Considerații privind uneltele din corn și os din stațiunea neolitică de la Liubcova - "Ornița". Apulum 25: 49-58.

Maigrot Y. 2001. Technical and functional study of ethnografic (Irian Jaya, Indonesia) and archaeological (Chalain and Clairvaux, Jura, Frace, 30th century BC) tools made from boars'tusks. In S. Beyries, P. Petrequin (eds.), Ethnoarchaeology and its transfers. Papers from a session held at the European Association of Archaeologists Fifth Annual Meeting in Bournemouth 1999. BAR International Series 983. Archaeopress. Oxford: 67-79. 
2005. Ivory, bone and antler tools production systems at Chalain 4 (Jura, France): late Neolithic site, $3^{\text {rd }}$ millennium. In H. Luik, A. M. Choyke, C. Batey, and L. Lougas (eds.), From Hooves to Horns, from Mollusc to Mammoth - Manufacture and Use of Bone Artefacts from Prehistoric Times to the Present. Proceedings of the $4^{\text {th }}$ Meeting of the ICAZ Worked Bone Research Group at Tallinn, 26th-31 st of August 2003. Muinasaja teadus 15. Tallinn Book Printers Ldt/Trükitud Tallinna Raamatutrükikojas. Tallin: 113-126.

Malyutina A., Charniauski M. 2021. Wild boar tusk artefacts from peat bog sites of north-western Russia and north-easternd Bellarus ( $4^{\text {th }}-2^{\text {nd }}$ mill. BC): technology, function, context. In S. Beyries, C. Hamon, and Y. Maigrot (eds.), Beyond use-wear traces: going from tools to people by means of archaeological wear and residue analyses. Sidestone Press. Leiden: 211-224.

Mantu C.-M., Turcanu S. 1999. Catalog. In V. Chirica, C.M. Mantu, and S. Turcanu (eds.), Scânteia. Cercetare arheologică și restaurare. Helios. Iași.

Marinescu-Bâlcu S., Beldiman C. 1997. Industria materiilor dure animale în cadrul culturii Starčevo-Cris pe teritoriul României: așezarea de la Grumăzeștii, jud. Neamt, Memoria Antiquitatis 21: 273-296.

Marinescu-Bîlcu S., Bolomey A. 2000. Drăgușeni. A Cucutenian Community. Editura Enciclopedică. București.

Marquebielle B. 2009. Mesolithic bone tools in Southwestern Europe: the example of the French site of "Le Cuzoul de Gramat". In B. Kufel-Diakowska, J. Baron (eds.), Written in Bones. Studies on technological and social contexts of past faunal skeletal remains. 7 th Meeting of the Worked Bone Research Group, September 7-11, 2009, Wroclaw, Poland. Wratislavia Antiqua. Uniwersytet Wrocławski, Instytut Archeologii. Wrocław: 63-79.

2014. Le travail des matières osseuses au Mésolithique. Caractérisation technique et économique à partir de séries du sud et de l'est de la France. Unpublished Ph.D. thesis. University of Toulouse 2 Le Mirail. Toulouse.

Mărgărit M., Vintilă C-M. 2015. New information from old collections. Reevaluation of personal adornments made of hard animal materials from the necropolis of Cernica. Studii de Preistorie 12: 81-115.

Mărgărit M., Boroneanț A. 2017a. Industria materiilor dure animale din situl mezolitic de la Alibeg (jud. Caraș-Severin). Materiale și Cercetări Arheologice XIII: 15-30.

2017b. The Mesolithic osseous industry from Răzvrata (the Iron Gates region). In M. Mărgărit, A. Boroneant, (eds.), From hunter-gatherers to farmers. Human adaptations at the end of the Pleistocene and the first part of the Holocene. Editura Cetatea de Scaun. Târgoviște: 81-92.

Mărgărit M., Vintilă C-M. 2018. Podoabe și figurine confectionate din materii dure animale descoperite în așezarea eneolitică de la Vidra (jud. Ilfov). Studii de preistorie 15: 73-105.

Mărgărit M., Dimache M. 2019. Personal adornments from the Eneolithic necropolis of Chirnogi-Spuvița Iorgulescu (Romania): a picture of prehistoric communities symbolism. Documenta Praehistorica 46: 398-413.

https://doi.org/10.4312/dp.46.25

Mărgărit M., Ștefan C. E., and Dumitrașcu V. 2014. Management of osseous materials for processing artifacts in the Boian settlement of Radovanu - La Muscalu (Romania). Archaeologia Bulgarica 18(3): 1-34.

Mărgărit M., Bălășescu A., and Mirea P. 2016. Exploatarea tehnologică a materiilor osoase în nivelul Dudești de la Măgura 'Buduiasca' ('Boldul lui Moș Ivănuș'), jud. Teleorman. Buletinul Muzeului Județean Teleorman. Seria Arheologie 8: 5-32.

Mărgărit M., Boroneant, A., Balint M., Bălăşescu A., and Bonsall C. 2017a. Interactiuni om-mediu în situl mezolitic de la Icoana (Porțile de Fier). Studii de Preistorie 14: 37-77.

Mărgărit M., Boroneant, A., and Bonsall C. 2017b. Analiza morfologică și functională a pieselor din materii dure animale din situl mezolitic de la Ostrovul Banului (jud. Mehedinti). Banatica 27: 39-72.

Mătasă C. 1946. Frumuşica. Village préhistorique à ceramique peinte dans la Moldavie du Nord. Monitorul Oficial și Imprimeria Statului. Imprimeria Națională. Bucuresti.

Nivois E., Brandt S., Gamelon M., and Baubet E. 2014. Le sanglier mâle: quand et comment devientil solitaire? Faune sauvage 302(1): 4-8.

Popușoi E., Beldiman C. 2001. Industria materiilor dure animale în așezarea neolitică timpurie (Starčevo-Criș) de la Trestiana, jud. Vaslui: ace de cusut. Memoria Antiquitatis 22: 21-62.

Schmid E. 1972. Atlas of Animal Bones. For Prehistorians, Archaeologists and Quaternary Geologists. Elsevier Publishing Company. Amsterdam, London, New York.

Sidéra I. 2000. L'outillage en os et en ivoire. In D. Ramseyer (ed.), Muntelier/Fischergässli. Un habitat néolithi- 
que au bord du lac de Morat (3895 à 3820 avant J.C.). Archéologie fribourgeoise 15. Editions Universitaires Fribourg Suisse. Fribourg: 118-156.

2008. Rubané, Villeneuve-Saint-Germain et Cardial: Filiations des Industries Osseuses. In L. Burnez-Lanotte, M. Ilett, and P. Allard (eds.), Fin des traditions danubiennes dans le Néolithique du bassin Parisien et de la Belgique (5100-4700 Av. J.-C.). Mémoire XLIV de la Société Préhistorique Française. Paris: 209-220.

2012. Nouveau regard sur la néolithisation. L'industrie osseuse de l'Anatolie au Bassin parisien via la Méditerranée. De Boccard. Paris.

Srejović D., Letica Z. 1978. Vlasac. Mezolitsko naselje u Đerdapu. Tom I. Arheologija. Posebna izdanja. Srpska akademija nauka i umetnosti. Beograd.

Stratton S., Griffiths S., Kogălniceanu R., +8 authors, and Whittle A. 2019. The Emergence of Extramural Cemeteries in Neolithic Southeast Europe: A Formally Modeled Chronology for Cernica, Romania. Radiocarbon 61(1): 319-346. https://doi.10.1017/RDC.2018.34

Ștefan Gh. 1925. Les fouilles de Căscioarele. Dacia II: 138-197.

Torcică I. 2017. Cultura Gumelnita în vestul Munteniei. Unpublished PhD thesis. "Vasile Pârvan" Institute of Archaeology. Romanian Academy. București.

Ursulescu N., Boghian D., Haimovici S., Cotiugă V., and Coroliuc A. 2002. Cercetări interdisciplinare în așezarea precucuteniană de la Tg. Frumos (jud. Iași). Aportul arheozoologiei. Acta Terrae Septemcastrensis I: 29-54.

Ursulescu N., Boghian D., and Cotiuga V. 2005. Problemes de la culture Precucuteni a la lumiére des recherches de Târgu Frumos (dep. de Iași). In V. Spinei, C. M. Lazarovici, and D. Monah (eds.), Scripta praehistorica. Miscel- lanea in honorem nonagenarii magistri Mircea Petrescu-Dîmbovita oblate. Editura Trinitas. Iași: 217- 260.

Ursulescu N., Tencariu F. A., Asăndulesei A., Vornicu D.-A., Vornicu-Terna A., and Mihu-Pintilie A. 2020. Așezarea precucuteniană de la Isaiia-Balta Popii (com. Răducăneni, jud. Iași, România) - cercetări arheologice interdisciplinare. Cercetări Arheologice XXVII: 113-140.

Voinea V., Grigoruță 0., and Cărpuș C. 2014. Hard animal material adornments discovered in Hamangia settlement from Cheia/Podoabe din materii dure animale descoperite în așezarea Hamangia de la Cheia. In M. Mărgărit, G. Le Dosseur, and A. Averbouh (eds.), An overview of the exploitation of hard animal materials during the Neolithic and Chalcolithic/O privire asupra exploatării materiilor dure animale de-a lungul neoliticului si calcoliticului. Cetatea de Scaun. Târgoviște: 101-136.

Vornicu A. 2014a. Technological behaviour in the manufacturing of bone pointed tools: a case study on the Chalcolithic settlement from Târgu Frumos (Iași County, Romania)/Comportamentul tehnologic în confectionarea vârfurilor: un studiu de caz din așezarea calcolitică de la Târgu Frumos (judetul Iași, România). In M. Mărgărit, G. Le Dosseur, and A. Averbouh (eds.), An overview of the exploitation of hard animal materials during the Neolithic and Chalcolithic/O privire asupra exploatării materiilor dure animale de-a lungul neoliticului si calcoliticului. Cetatea de Scaun. Târgoviște: 137-154.

2014b. Artefactele din materii dure animale. In D. Boghian, S. C. Enea, S. Ignătescu, L. Bejenaru, and S. M. Stanc (eds.), Comunitătile cucuteniene din zona Târgului Frumos. Cercetări interdisciplicare in siturile de la Costesti și Giurgești. Editura Universitătii "Alexandru Ioan Cuza". Iași: 51-60.

Vulpe R. 1953. Săpăturile de la Poienești din 1949. Materiale si cercetări arheologice 1: 213-506. 


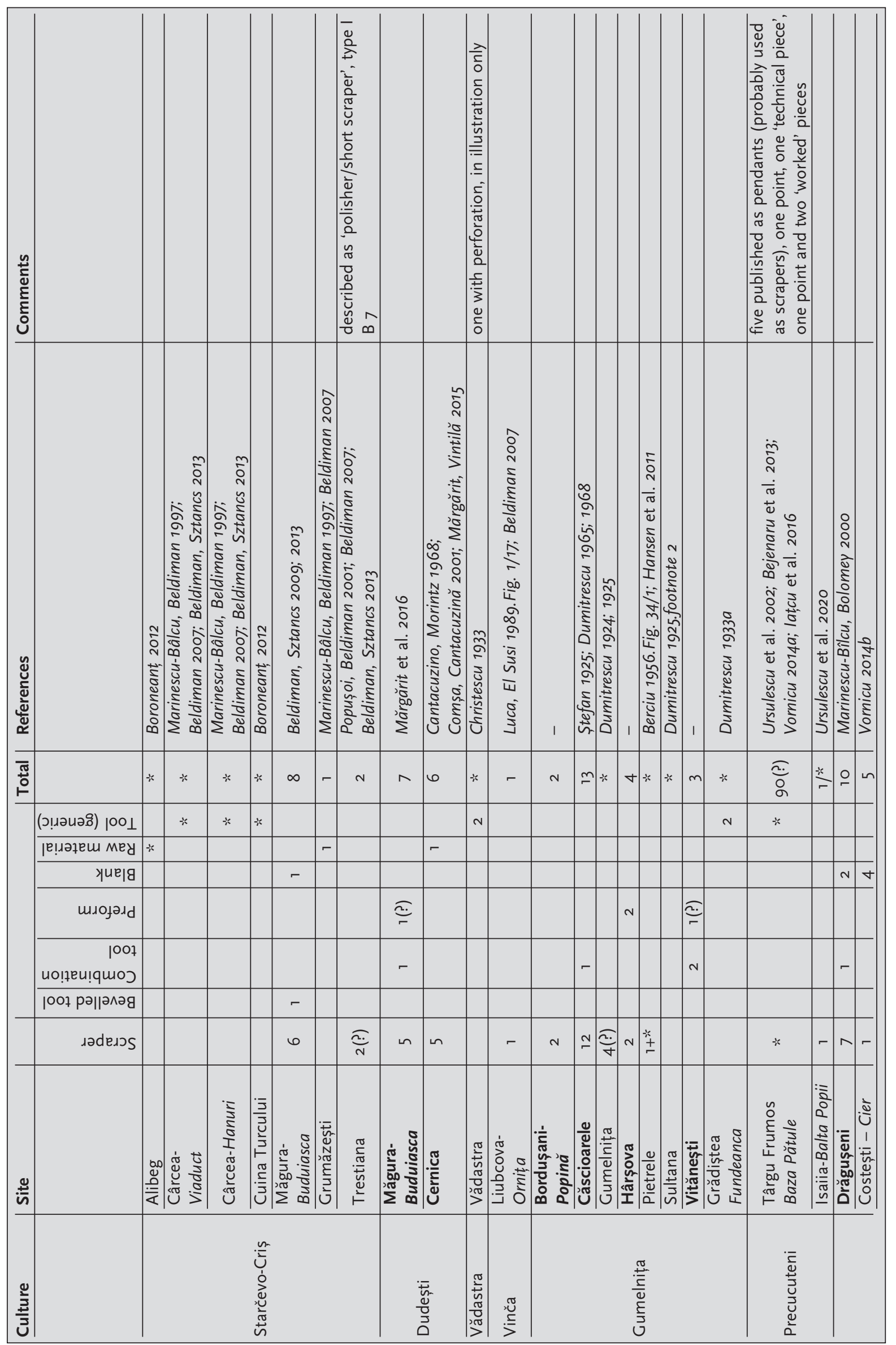




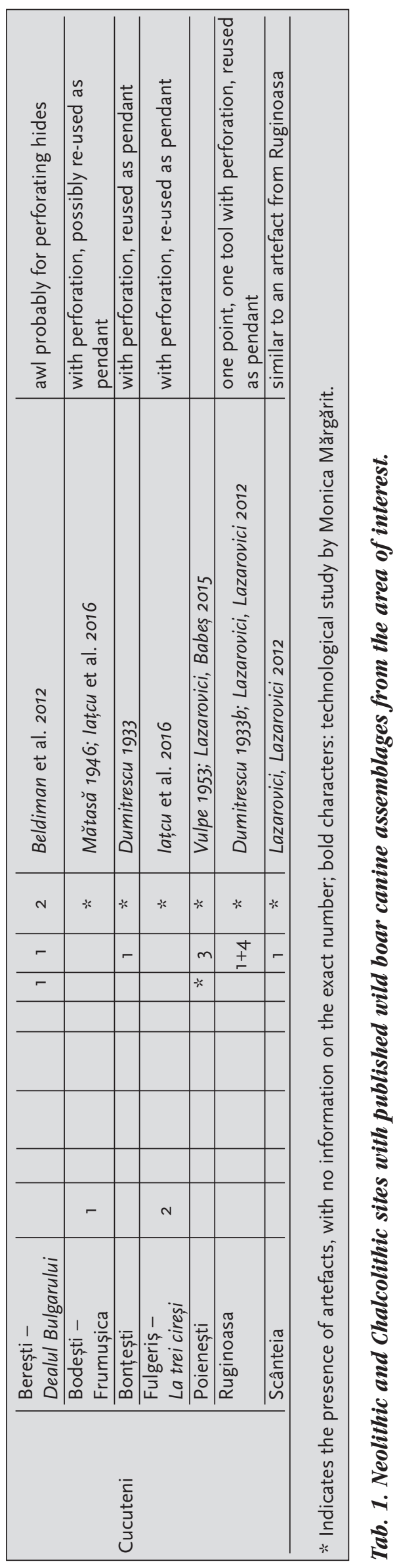

